\title{
Internet Penetration and the Environmental Kuznets Curve: A Cross-National Analysis
}

\author{
Zhenbo Zhang ${ }^{1} \mathbb{D}$ and Xiaohua Meng ${ }^{2, *}$ \\ 1 School of Public Administration, Nanjing Audit University, 86 West Yushan Road, Nanjing 211815, China; \\ zhangzb@nau.edu.cn \\ 2 Collaborative Innovation Center for Newtype Urbanization and Social Governance of Jiangsu Province, \\ Soochow University, 199 Renai Road, Suzhou 215006, China \\ * Correspondence: mengxiaohua@suda.edu.cn
}

Received: 11 February 2019; Accepted: 28 February 2019; Published: 5 March 2019

\begin{abstract}
The internet has revolutionized the pattern of economic growth and its environmental effects. We investigate the ways in which internet penetration influences the relationship between income and the environment using data from 1996 to 2014 on $\mathrm{CO}_{2}$ emissions from 115 countries with multiple levels of per capita GDP and internet penetration. Empirical results document the existence of the Environmental Kuznets Curve (EKC) and reveal that internet penetration does generally reduce the actual income level beyond which pollution begins to decrease. Further tests, based on the division of income and period, indicate an increasing negative influence of internet penetration on emissions reduction, with income growth and the environmental effect of the internet evolving from direct and indirect to systemic. We discuss this study's contributions to further research on income-environment paths and implications for the role of the internet in emissions reduction.
\end{abstract}

Keywords: the Environmental Kuznets Curve; internet penetration; income level; emissions reduction

\section{Introduction}

The Environmental Kuznets Curve (EKC) hypothesis has been widely tested and taken as an explanation for the evolution of environmental quality with income increasing [1-3]. The EKC postulates an inverted U-shaped nexus of income-environment paths; that is, environment deteriorates because of economic growth at first, but eventually reaches an improvement in environmental quality with further income growth, after arriving at a threshold.

Based on the substantial empirical evidence that exists, the EKC has generally been accepted as an empirical regularity [4]. Nevertheless, the level of income past which environment begins to improve - the turning point of the EKC-is still controversial in a cross-national context [5-7]. This kind of heterogeneity generally occurs due to the different levels of income among different countries, as governments in less developed countries inevitably face greater pressure in regard to economic growth and therefore pay more attention to it [2,6]. Al-Mulali, Saboori, and Ozturk (2015) even conclude after a comprehensive literature review that the EKC hypothesis could be valid only in countries with higher income levels [8]. Moreover, as noted by Baiardi (2014), it is only in recent years that the examination of the income-pollution nexus in developing countries has started to receive attention [9]. This study focuses on this controversy and aims to provide an interpretation mechanism by exploring the factors that explain the formulation and evolution of the EKC relationship. According to Grossman and Kruger's original study (1991), the EKC hypothesis actually assumes diverse income-environment paths because of the cross-national heterogeneity in economic scale, economic composition, and technology sophistication, which are the three mechanisms that affect the evolution of environment quality with economic growth [1]. The technique effect suggests that a 
positive relationship exists between technological sophistication and the environment because of the renovation and international transfer of cleaner technology. However, in recent decades there appear to have been increasing arguments regarding the environmental impact of technology, along with the rapid diffusion and penetration of information and communication technology (ICT) and internet use [10].

Among others, Wang and Hao (2018), Gonel and Akinci (2018), and Williams (2011) argue that internet penetration has made the environmental effects of technological progress more comprehensive and, consequently, has led to a countervailing impact on environmental evolution [11-13]. From the perspective of the sustainability community, internet penetration genetically has positive impacts on environmental evolution. This is because it has substantially transformed the forms of production and the ways in which we communicate and work. This discovery has uncovered feasible possibilities in regard to achieving sustainability through the use of new energy- optimized and dematerialized alternatives [12,14-17]. Internet use also enables dynamic support for efficient environmental governance and extensive sustainable behaviors. Internet-based government processes are commonly known as e-governments. As noted by Gonel and Akinci (2018), Purdy (2017), and West (2004), e-government development could improve policy effectiveness, governing efficiency, and democratic responsiveness $[12,18,19]$; consequently, it could cultivate ecological awareness, inspiring sustainable behaviors and e-participation with the aim of achieving ecological sustainability $[10,11,20,21]$.

Nevertheless, increasing numbers of studies have revealed that the diffusion of internet technology has significantly contributed to carbon emissions, because of its exponentially growing energy consumption and resource depletion in the manufacturing of internet-related products [14,22,23]. More evidence in recent research suggests that the operation of internet-driven applications generally emits more carbon dioxide than the equivalent manufacturing process $[24,25]$. The process of global transportation and e-waste disposal also leads to substantial energy consumption and carbon emissions [26]. This is especially the case when we consider the way in which ICT and internet-based products generally have a short service life (two to five years) [14]. In this light, Dinda (2004) warned that society should be cautious about the latent environmental impacts of adopting new technologies [2].

Regardless of any countervailing effects, the positive and negative environmental impacts of internet penetration do not exist co-instantaneously with equivalent influence on the evolution of environmental quality at all times. Economic development gives rise to the evolution of the environmental influence of internet penetration from direct and indirect to systemic [13]. Direct effects comprise the environmental benefits of internet-based applications and the tremendous e-waste they emit as a by-product, which is detrimental to the natural environment. This is followed by indirect effects, consisting of structural change, which lead to effective energy consumption and dematerialized production, as well as negative impacts caused by incomplete substitution [27]. Systemic effects are based on the wide application of the internet at the economic and societal levels, ranging from internet-based sustainable production and consumption to internet-enhanced environmental governance mechanisms. Systemic effects highlight the positive environmental effect of internet penetration, emphasizing the fact that the evolution of environmental quality depends on the influence of both pollution and protection activities [28]. That is, the direct effect of internet diffusion comes first and is embodied in a boost in the growth of ICT and other related industries, leading to both positive and negative influences on the environment. Systemic effect is reflected in the stimulation of sustainable economic and societal change through environmental sociology. In general, the overall environmental impact of internet penetration may vary with its transformation process from direct economic influence to systemic influence, at both the economic and societal levels.

To the best of our knowledge, although it has been a stylized fact that the internet has impacts on both environmental evolution and economic growth [29], no empirical EKC literature explicitly introduces internet penetration as an explanatory variable. The effects of ICT progress and internet use are generally represented indirectly, by proxies such as environmental research expenditure $[9,30]$, 
renewable energy production and/or energy efficiency [7,8], international trade [2,31], institutional quality [6], and linear time trends [28]. This study, for the first time, sheds light on the impact of internet penetration on the EKC and its economic threshold; that is, the level of income beyond which pollution starts to decrease (see Figure 1). More specifically, we further investigate the heterogeneity in the environmental effects of internet penetration among countries with different income levels and development stages.

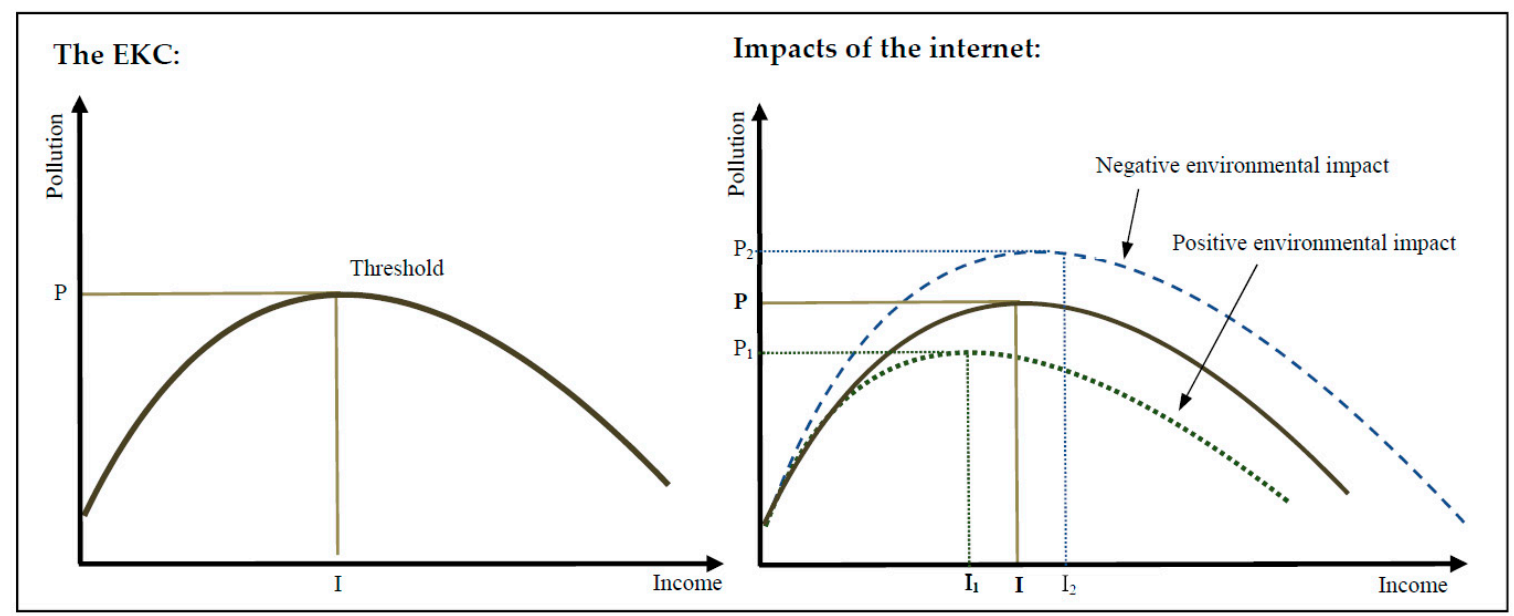

Figure 1. The original income-pollution relationship and the impacts of the internet on the Environmental Kuznets Curve (EKC).

This analysis constructs a new specification for the EKC, based on the model developed by Bradford, Fender, Shore, and Wagner (2005) [32], using data from 1996 to 2014 on $\mathrm{CO}_{2}$ emissions from 115 countries with multiple levels of per capita GDP and internet penetration. Empirical results document the existence of the EKC and the overall negative impact of internet penetration on its economic threshold. Further tests reveal that internet penetration is positively correlated to the economic threshold of the EKC in low-income countries, while this is negative for developed countries. Our findings indicate that the internet has an overall positive impact on the improvement of environmental quality; nevertheless, the specific environmental effect of internet penetration for each country may vary with the level of income and the sustainable evolution that exists at the societal level. In low-income countries, the diffusion and penetration of the internet (direct effects) would be more beneficial for economic growth than for environmental quality; therefore, further systemic measures should be put in place in order to reduce emissions.

This study contributes to the extant literature by expanding on the theoretical explanation of the environmental effects of internet penetration in the global context. It reveals that the environmental effects of internet penetration vary with economic conditions and development stages. This differs from, and goes beyond, the argument concerning the positive/negative environmental effects of the internet described in the existing literature, positing a new perception of the role of the internet in the reduction of emissions

In the remainder of this article, we first provide the materials and methodology used, along with the variables and data collection in the Section 2. Section 3 reports the descriptive statistics and empirical results of the model. Section 4 presents the discussion and conclusions.

\section{Materials and Method}

\subsection{Research Methods}

This study builds upon the EKC model developed by Bradford, Fender, Shore, and Wagner (2005) [32] and has been theoretically and empirically confirmed by Wagner (2008), Leitão (2010), Baiardi (2014), and others [9,33,34]. It is an analytical method that circumvents econometric problems 
that arise in traditional EKC functional forms with quadratic transformations of regressors. The model is organized as follows

$$
\frac{\partial P_{t}}{\partial t}=\alpha\left(y-y^{*}\right) g
$$

In Equation (1), the instantaneous change of pollution $(P)$ is interpreted by the economic growth rate, $g$, and the distance of economic level, $y$, to the economic threshold, $y^{*}$. Note that, if the country is at a stage of economic development (that is, $g>0$ ), then pollution increases $\left(\partial P_{t} / \partial t>0\right)$ until the threshold $y^{*}$ is reached $\left(y<y^{*}\right)$, or decreases $\left(\partial P_{t} / \partial t<0\right)$ when the threshold $y^{*}$ is passed $\left(y>y^{*}\right)$, on the condition that the coefficient $\alpha<0$. Similarly, if the country faces a fall in the economy (referring to a negative growth rate, $g)$, then pollution decreases $(\partial P t / \partial t<0)$ when $y<y^{*}$, or increases $(\partial P t / \partial t>0)$ when $y>y^{*}$, on the condition that the coefficient $\alpha<0$. To summarize, if only $\alpha<0$, Equation (1) predicts an inverted U-shaped relationship between income and environment.

For the purpose of testing the influence of internet penetration on the EKC (i.e., the turning point), we hypothesize that

$$
y^{*}=\delta_{1}+\delta_{2} \text { Inter }
$$

where Inter is the level of internet penetration. According to Equation (2), a country's income level, corresponding to the threshold of the EKC, is a function of internet penetration. As long as $\delta_{2}<0$, then there exists a negative relationship between Inter and $y^{*}$; that is to say, the higher the level of internet penetration, the less actual income level beyond which environmental quality starts to improve.

Substituting Equation (2) into (1), we obtain

$$
\frac{\partial P_{t}}{\partial t}=\alpha\left[y-\left(\delta_{1}+\delta_{2} \text { Inter }\right)\right] \mathrm{g}
$$

We then turn Equation (3) into a time integral equation, where $y$ and $g$ are constant in time, to get

$$
P_{t}=\mu+\alpha\left[y-\left(\delta_{1}+\delta_{2} \text { Inter }\right)\right] g t
$$

where $\mu$ is a constant of integration. Integrating the Equation (4) with respect to country $(i)$, and adding the control variables $\left(C_{i, t}\right)$ and the stochastic error term $\left(\varepsilon_{i, t}\right)$, finally leads to

$$
\ln P_{i, t}=\mu_{i}+\beta_{0}\left(\mathrm{y}_{i} \mathrm{~g}_{i} t\right)+\beta_{1}\left(\mathrm{~g}_{i} t\right)+\beta_{2}\left(\text { Inter }_{i, t} \mathrm{~g}_{i} t\right)+\beta_{3} C_{i, t}+\varepsilon_{i, t}
$$

where $i$ and $t$ refer to the countries and time period, respectively. $\ln P_{i, t}$ denotes the natural logarithm of per capita $\mathrm{CO}_{2}$ emissions. A common view that exists in environmental research is that most of the buildup of greenhouse gasses is the result of increasing $\mathrm{CO}_{2}$ discharges, which are believed to account for at least $60 \%$ of global warming [6]. $y_{i}$ and $g_{i}$ designate the average income level and income growth of country $i$ during the sample period, respectively. Inter $r_{i, t}$ is proxied by the level of internet penetration in country $i$ in year $t$. We employ the year-to-year data, rather than the average level of internet penetration for each country, aiming to capture the different influences of internet penetration in different stages of development, considering the apparent gap of internet diffusion between developed and less developed countries [35].

Among the control variables $\left(C_{i, t}\right)$ in Equation (5), the levels of urbanization and industrialization capture the environmental influences of socioeconomic development [6,36]. Demographic factors, including aging rate, proportion of women, and population density and growth, are common in the EKC literature [30,37-40]. An indicator of democracy is also included to help us understand the impact of law, institutions, and civil liberty on emissions, which is still subject to controversy in the environmental literature [41-43].

The validity of the EKC hypothesis is examined in Equation (5) by confirming if the coefficient $\alpha=\beta_{0}<0$. The influence of internet penetration on the turning point of the EKC can be checked by testing the coefficient $\delta_{2}=-\beta_{2} / \alpha<0$; that is, $\beta_{2}<0$, giving $\alpha<0$. 
However, evidence has been found that internet penetration can influence not only the economic threshold of the EKC, but also the economic growth of one country [29]. Therefore, the indirect effect of internet penetration on environment through economic indicators $\left(y_{i}\right.$ and $\left.g_{i}\right)$ must be included. Using a methodology similar to Leitão (2010) and Baiardi (2014) [9,34], we build Equation (6) to capture the indirect effects:

$$
Y_{i, t}=\lambda_{i}+\tau_{t}+\psi_{1} \text { Inter }_{i, t}+\psi_{2} X_{i, t}+\zeta_{i, t}
$$

where $\lambda_{i}$ and $\tau_{t}$ denote the country and time fixed effects, respectively, and $\zeta_{i, t}$ denotes the error term. Real per capita GDP $(Y)$ is explained by internet penetration $\left(\right.$ Inter $\left.r_{i, t}\right)$ and control variables $\left(X_{i, t}\right)$, including investment intensity, electricity consumption, trade, foreign direct investment (FDI), and inflation rate, in accordance with the recent growth literature [34,44-46]. In this equation, the lagged internet penetration and investment intensity are used to eliminate the potential endogenous problems.

\subsection{Sample and Data}

To fulfill Equations (5) and (6), and to investigate how internet penetration impacts the income-emission nexus in a cross-national context, 115 countries with multiple levels of per capita GDP from 1996 to 2014 are included in this analysis (see Table 1). Other countries are dropped from the sample pool mainly because of missing data on $\mathrm{CO}_{2}$ emissions (e.g., Eritrea, Montenegro, Serbia, and Timor-Leste) and per capita GDP (e.g., Afghanistan, Syria, the DPR Korea, Qatar, Libya, the Maldives, Sao Tome and Principe, and Somalia).

Table 1. Sample countries grouped by income (115 countries).

\begin{tabular}{|c|c|}
\hline Income Group & Country \\
\hline Low-income countries & $\begin{array}{l}\text { Benin, the Democratic Republic of the Congo, Ethiopia, Eritrea, Mozambique, Nepal, } \\
\text { Niger, Senegal, Togo, and Zimbabwe. }\end{array}$ \\
\hline Lower middle-income countries & $\begin{array}{l}\text { Armenia, Bangladesh, Bolivia, Cambodia, Cameroon, Egypt, El Salvador, Georgia, Ghana, } \\
\text { Guatemala, Honduras, India, Indonesia, Jordan, Kenya, Kyrgyzstan, Moldova, Mongolia, } \\
\text { Morocco, Myanmar, Nicaragua, Nigeria, Pakistan, the Philippines, Sudan, Tajikistan, } \\
\text { Tunisia, Uzbekistan, and Yemen. }\end{array}$ \\
\hline Upper middle-income countries & $\begin{array}{l}\text { Albania, Algeria, Argentina, Belarus, Botswana, Brazil, Bulgaria, China, Colombia, Costa } \\
\text { Rica, Croatia, Cuba, the Dominican Republic, Ecuador, Iran, Jamaica, Kazakhstan, Lebanon, } \\
\text { Macedonia, Malaysia, Mauritius, Mexico, Montenegro, Namibia, Panama, Paraguay, Peru, } \\
\text { Romania, Russia, South Africa, Suriname, Thailand, Turkey, and Venezuela. }\end{array}$ \\
\hline High-income countries & $\begin{array}{l}\text { Australia, Austria, Bahrain, Belgium, Brunei Darussalam, Canada, Chile, Cyprus, the } \\
\text { Czech Republic, Denmark, Estonia, Finland, France, Germany, Greece, Hungary, Iceland, } \\
\text { Ireland, Israel, Italy, Japan, Kuwait, Latvia, Lithuania, Luxembourg, Malta, the } \\
\text { Netherlands, New Zealand, Norway, Oman, Poland, Portugal, Qatar, the Republic of } \\
\text { Korea, Slovakia, Slovenia, Spain, Sweden, Switzerland, the United Kingdom, the United } \\
\text { States of America, and Uruguay. }\end{array}$ \\
\hline
\end{tabular}

Notes: Following the World Bank guidelines (2017 GNI per capita), the four income groups are divided based on the following income criteria; $\leq \$ 995, \$ 996$ to $\$ 3895, \$ 3896$ to $\$ 12055$, and $>\$ 12055$.

Table 2 presents the definitions and data sources of the variables. Equation (6) is conducted first with the $Y_{i, t}$ as the dependent variable, to obtain the fitted values $y_{i}$ and $g_{i}$, which are introduced as economic indicators in Equation (5). Specifically, $y_{i}$ is the average of the fitted values of country $i$ over the study period. $g_{i}$ is computed from $y_{i}^{1}=y_{i}^{2}\left(g_{i}+1\right)^{\wedge} 15$, assuming $y_{i}^{1}$ is the average of the fitted values of country $i$ across the latest four years; $y_{i}^{2}$ is the average across the first four years. Bradford, Fender, Shore, and Wagner (2005) used this method to eliminate the short-term cyclical influences in economic development [32]. The data regarding democracy indicators are from Freedom House, and the world development indicators (WDIs) provide other initial data. 
Table 2. Variable definitions and data sources.

\begin{tabular}{cll}
\hline Variable & \multicolumn{1}{c}{ Definition } & Data source \\
\hline$P$ & Natural logarithm of per capita $\mathrm{CO}_{2}$ emissions & WDI \\
$Y$ & $\begin{array}{l}\text { Real per capita GDP (2010 US dollars) } \\
\text { Natural logarithm of the fitted value of country's } \\
\text { average real per capita GDP }\end{array}$ & WDI \\
Country's annual growth rate based on the fitted & WDI \\
Inter & value of real per capita GDP & WDI \\
Individuals using the internet per 10 people & WDI \\
Investment intensity & The share of investment in GDP & WDI \\
Electricity consumption & Natural logarithm of electricity consumption (per & WDI \\
Trade & capita kilowatt-hour) & WDI \\
FDI & The share of trade in GDP & WDI \\
Inflation rate & The share of foreign direct investment in GDP & WDI \\
Urbanization & Rate of inflation (GDP deflator) & WDI \\
Industrialization & Urban population of total & WDI \\
Aging rate & The share of industrial added value in GDP & WDI \\
Popu-density & Elderly population ( $\geq 60$ ) of total & WDI \\
Popu-growth & Population density (people per sq. km of land area) & WDI
\end{tabular}

Both fixed and random effects are estimated for Equations (5) and (6), as in Bradford, Fender, Shore, and Wagner (2005), Leitão (2010), and Baiardi (2014) [9,32,34]. We selectively present one of the two sorts of results, according to the Hausman test. STATA 14.0 is used to fulfill the calculation process.

\section{Results}

\subsection{Descriptive Statistics}

We first present descriptive statistics of the main variables. Table 3 provides the means and standard deviations of the total sample and subsamples divided by income levels. With income level rising ceaselessly, there are apparent increments of $\mathrm{CO}_{2}$ emission, internet penetration, electricity consumption, trade, FDI, urbanization, industrialization, and aging rate, and decrements in inflation rate, population growth, and Democratization (a reverse indicator that indicates an increase in democracy level if it decreases). As shown in the table below, there are significant differences in the mean values of the variables among countries with different economic conditions (the associated $p$-value is less than 0.05).

Table 3. Descriptive statistics of the main variables grouped by income division.

\begin{tabular}{|c|c|c|c|c|c|c|c|c|c|c|c|}
\hline \multirow{2}{*}{ Variable } & \multirow{2}{*}{ Mean } & \multirow{2}{*}{ S.D. } & \multicolumn{2}{|c|}{ Low } & \multicolumn{2}{|c|}{ Lower middle } & \multicolumn{2}{|c|}{ Upper middle } & \multicolumn{2}{|c|}{ High } & \multirow{2}{*}{ Sig. of $F$} \\
\hline & & & Mean & S.D. & Mean & S.D. & Mean & S.D. & Mean & S.D. & \\
\hline $\ln P$ & 0.98 & 1.45 & -1.81 & 1.01 & -0.12 & 0.88 & 1.21 & 0.67 & 2.20 & 0.60 & 0.000 \\
\hline Inter & 2.55 & 2.75 & 0.22 & 0.35 & 0.89 & 1.19 & 1.92 & 1.87 & 4.72 & 2.91 & 0.000 \\
\hline Investment intensity & 0.23 & 0.08 & 0.19 & 0.11 & 0.23 & 0.07 & 0.25 & 0.08 & 0.23 & 0.07 & 0.001 \\
\hline Electricity consumption & 4176.3 & 5617.1 & 176.4 & 218.4 & 775.8 & 241.7 & 2333.3 & 1309.0 & 8903.4 & 2875.0 & 0.000 \\
\hline Trade & 0.65 & 0.32 & 0.50 & 0.18 & 0.61 & 0.27 & 0.62 & 0.31 & 0.72 & 0.35 & 0.000 \\
\hline FDI & 5.07 & 17.99 & 3.58 & 5.85 & 3.58 & 4.16 & 3.83 & 4.14 & 7.44 & 5.90 & 0.001 \\
\hline Inflation rate & 10.44 & 64.40 & 28.16 & 199.00 & 11.32 & 21.70 & 13.24 & 42.93 & 3.38 & 5.27 & 0.000 \\
\hline Urbanization & 0.61 & 0.21 & 0.29 & 0.10 & 0.45 & 0.15 & 0.64 & 0.14 & 0.78 & 0.12 & 0.000 \\
\hline Industrialization & 0.31 & 0.13 & 0.22 & 0.07 & 0.29 & 0.07 & 0.33 & 0.09 & 0.32 & 0.18 & 0.000 \\
\hline Aging rate & 0.09 & 0.05 & 0.03 & 0.01 & 0.05 & 0.02 & 0.08 & 0.04 & 0.13 & 0.05 & 0.000 \\
\hline Popu-density & 4.11 & 1.32 & 3.85 & 0.79 & 4.29 & 1.18 & 3.78 & 1.30 & 4.32 & 1.45 & 0.000 \\
\hline Popu-growth & 0.01 & 0.02 & 0.03 & 0.01 & 0.02 & 0.01 & 0.01 & 0.01 & 0.01 & 0.02 & 0.000 \\
\hline Proportion of women & 0.40 & 0.09 & 0.47 & 0.05 & 0.36 & 0.11 & 0.39 & 0.08 & 0.42 & 0.08 & 0.000 \\
\hline Democratization & 6.13 & 3.74 & 8.85 & 2.80 & 8.49 & 2.92 & 6.79 & 3.27 & 3.38 & 2.87 & 0.000 \\
\hline
\end{tabular}

Notes: S.D. stands for standard deviation. The last column reports the estimation results of variance concerning the differences among income groups. 


\subsection{Empirical Results}

Table 4 presents the estimation results of Equation (6). Column $(Y 1)$ examines the influence of internet penetration $\left(\right.$ Inter $\left._{i, t}\right)$ on real per capita GDP $\left(Y_{i, t}\right)$. In columns $(Y 2)$ to $(Y 6)$, explanatory variables of Investment intensity $y_{i, t}$, Electricity consumption ${ }_{i, t}$, Trade $_{i, t}, \mathrm{FDI}_{i, t}$, and Inflation rate $e_{i, t}$ are added incrementally. In all models, there exists a significant positive relationship between internet penetration (Inter $\left.r_{i, t}\right)$ and economic condition $\left(Y_{i, t}\right)\left(\psi_{1}>0, p<0.001\right)$, which is consistent with our expectations. Additionally, investment intensity and electricity consumption have significant positive impacts on income growth $(p<0.001)$, while no consistent relationship was found between trade, FDI, and inflation rate, and the real per capita GDP. We present the fixed-effect analysis results in accordance with the significant Hausman test statistics, as listed in the table below. The fixed-effect analysis is suggested in the cross-national growth literature [9,32,34]. Given these facts and the higher value of $R^{2}(0.73)$, the economic indicators in Equation (5) - $y_{i}$ and $g_{i}$-are calculated from the fitted values of $Y_{i}$ in model $(Y 3)$.

Table 4. Estimation results for real per capita GDP: The role of internet penetration.

\begin{tabular}{|c|c|c|c|c|c|c|}
\hline Dependent Variable $Y$ & (Y1) & $(Y 2)$ & (Y3) & $(Y 4)$ & (Y5) & $(Y 6)$ \\
\hline Inter $_{i, t}$ & $880.09^{* * *}$ & $879.43^{* * *}$ & $843.11^{* * *}$ & $803.93^{* * *}$ & $792.97 * * *$ & $792.33^{* * *}$ \\
\hline Investment intensity ${ }_{i, t}$ & & $2719.65^{* * *}$ & $2922.87^{* * *}$ & $3096.59 * * *$ & $2979.27^{* * *}$ & $2944.90^{* * *}$ \\
\hline Electricity consumption $_{i, t}$ & & & $0.19^{* * *}$ & $0.20^{* * *}$ & $0.21^{* * *}$ & $0.21^{* * *}$ \\
\hline Trade $_{i, t}$ & & & & 46.28 & 7.83 & 20.15 \\
\hline $\mathrm{FDI}_{i, t}$ & & & & & -0.34 & -0.32 \\
\hline Inflation rate rat $_{i, t}$ & & & & & & 0.25 \\
\hline Constant & $12,988.02 * * *$ & $12,435.75^{* * *}$ & $11,719.15^{* * *}$ & $11,628.37^{* * *}$ & $11,551.41 * * *$ & $11,529.72^{* * *}$ \\
\hline$R^{2}$ & 0.71 & 0.69 & 0.73 & 0.73 & 0.75 & 0.75 \\
\hline$F$ value & $2392.77^{* * *}$ & $1213.07^{* * *}$ & $843.06^{* * *}$ & $700.48^{* * *}$ & $550.55^{* * *}$ & $456.59^{* * *}$ \\
\hline Hausman test & $196.67^{* * *}$ & $200.71^{* * *}$ & $207.18^{* * *}$ & $222.16^{* * *}$ & $239.99^{* * *}$ & $240.93^{* * *}$ \\
\hline Obs. & 2147 & 2133 & 2124 & 2121 & 2083 & 2082 \\
\hline
\end{tabular}

Notes: ${ }^{* * *} p<0.001$. The lagged Inter ${ }_{i, t}$ and Investment intensity $y_{i, t}$ are used. Results of the fixed-effect analysis are reported.

The examination of the results of Equation (5) can be seen in Table 5. Column (P1) shows the results for the control variables. Column $(P 2)$ and column (P4), respectively, show the empirical results for the EKC when the impact of internet penetration is ignored, without and with the control variables. Column (P3) and column (P5) add the effect of internet penetration. The independent variables ygt and $g t$ both have significant relationships with per capita $\mathrm{CO}_{2}\left(\beta_{0}<0, p<0.001 ; \beta_{1}>0, p<0.001\right)$, evidencing the validity of the EKC. The results also show that the variable Intergt is significantly and negatively correlated with the dependent variable $\left(\beta_{2}<0, p<0.001\right)$, indicating that a higher level of internet penetration in a country indicates less per capita GDP, corresponding to the threshold of the EKC (i.e., the $\left.y^{*}\right)$.

Table 5. Analysis to estimate the income-emission nexus and the impact of the internet.

\begin{tabular}{cccccc}
\hline Dependent Variable $\ln P$ & $\mathbf{( P 1 )}$ & $\mathbf{( P 2 )}$ & $\mathbf{( P 3 )}$ & $\mathbf{( P 4 )}$ & $\mathbf{( P 5 )}$ \\
\hline$y g t$ & & $-1.391^{* * *}$ & $-0.986^{* * *}$ & $-1.319^{* * *}$ & $-0.959^{* * *}$ \\
$g t$ & $14.226^{* * *}$ & $11.332^{* * *}$ & $13.532^{* * *}$ & $10.958^{* * *}$ \\
Intergt & & $-0.184^{* * *}$ & & $-0.162^{* * *}$ \\
Urbanization & $2.502^{* * *}$ & & & $2.302^{* * *}$ & $1.845^{* * *}$ \\
Industrialization & $0.848^{* * *}$ & & & $0.630^{* * *}$ & $0.403^{* * *}$ \\
Aging rate & $-0.845^{*}$ & & & $-5.218^{* * *}$ & $-2.253^{* * *}$ \\
Popu-density & $0.361^{* * *}$ & & & 0.010 & $-0.208^{* * *}$ \\
Popu-growth & $1.737^{*}$ & & & $1.608^{*}$ & $2.217^{* * *}$ \\
Proportion of women & $-0.812^{* *}$ & & & $-0.882^{* *}$ & $-0.871^{* * *}$ \\
Democratization & $-0.016^{* *}$ & & & $-0.014^{* *}$ & $-0.015^{* * *}$ \\
Constant & $-1.838^{* * *}$ & $0.873^{* * *}$ & $0.811^{* * *}$ & 0.103 & $1.020^{* * *}$ \\
$R^{2}$ & 0.222 & 0.136 & 0.254 & $0.261^{* * *}$ & 0.326 \\
F value & $78.51^{* * *}$ & $149.34^{* * *}$ & $213.69^{* * *}$ & $70.14^{* * *}$ & $85.83^{* * *}$ \\
Hausman test & $114.98^{* * *}$ & 5.82 & $142.89^{* * *}$ & $152.72^{* * *}$ & $196.39^{* * *}$ \\
Obs. & 2053 & 2016 & 2000 & 1914 & 1901 \\
\hline
\end{tabular}

Notes: ${ }^{* *} p<0.001 ;{ }^{* *} p<0.01 ;{ }^{*} p<0.05$. Results of the fixed-effect analysis are reported. 
Among the control variables, as shown in column (P5) of Table 5, urbanization, industrialization, and population growth demonstrate positive effects on $\mathrm{CO}_{2}$ discharge, which is consistent with previous research [47-49]. However, the more elderly and female the population in a country is, the less amounts the country will emit greenhouse gases. Moreover, we provide empirical evidence supporting the argument that a democratic country tends to discharge more emissions [50,51].

Furthermore, we carry out separate analyses based on the division of income and period in order to test the environmental effects of internet penetration in different economic conditions and development stages. The regression results are shown in Table 6.

Table 6. Separate analyses based on the division of income and period.

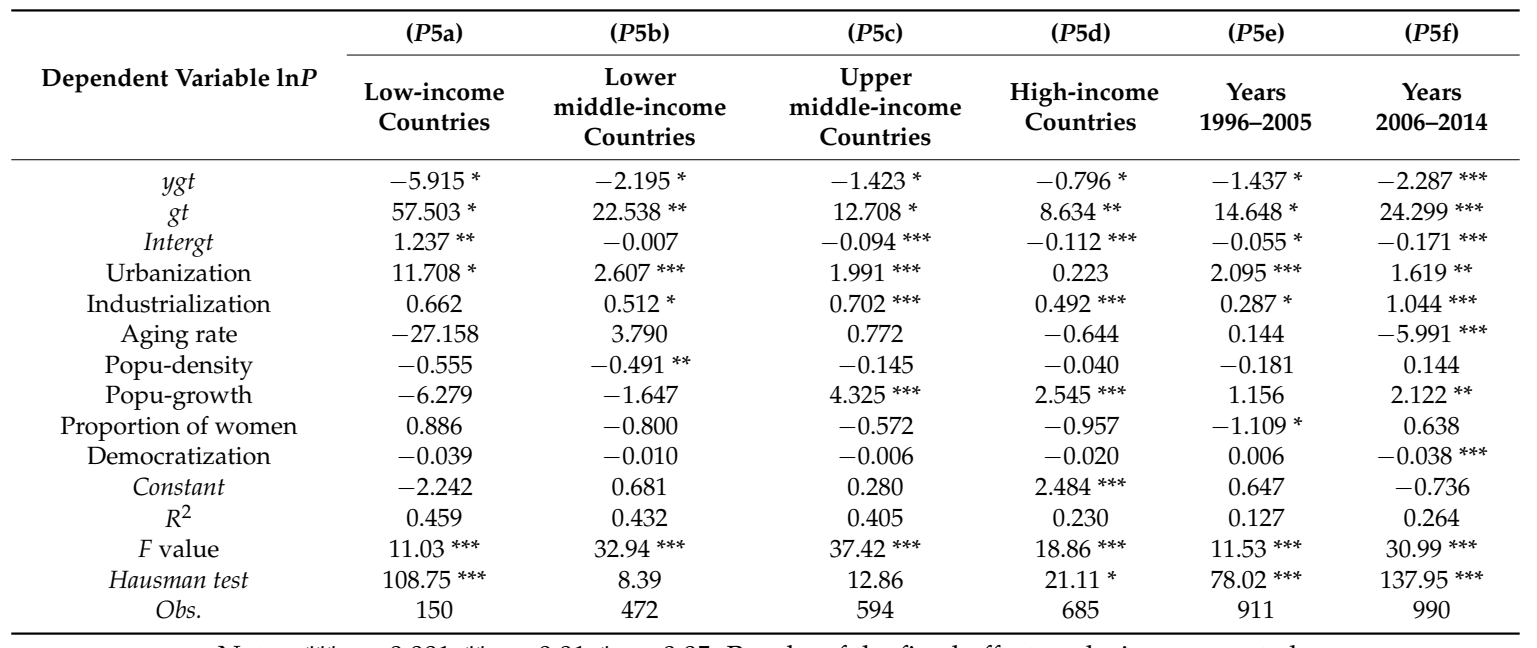

Notes: ${ }^{* * *} p<0.001 ;{ }^{* *} p<0.01 ;{ }^{*} p<0.05$. Results of the fixed-effect analysis are reported.

Columns (P5a) to $(P 5 \mathrm{~d})$ depicts the results of the multiple regression based on income division and show that the EKC exists in every income group $\left(\beta_{0}<0, p<0.05\right)$, while the impact of the internet varies according to the income division. The explanatory variable Intergt has significant positive impacts on $\mathrm{CO}_{2}$ emission intensity in low-income countries $\left(\beta_{2}>0, p<0.01\right)$, while, in middle-higherand high-income countries, the nexus turns negative $\left(\beta_{2}<0, p<0.001\right)$.The results demonstrate that the diffusion of internet use raises the actual income level beyond the point at which pollution begins to decrease in low-income countries, in contrast with the increasing positive environmental effects regarding income growth and internet penetration. The relative results depicted in columns (P5e) and (P5f) further support our expectations. Although the negative effects of internet penetration on the turning point exist in both period stages, the absolute value of the coefficient of Intergt increases from 0.055 in the years 1996 to 2005, to 0.171 in the years 2006 to 2014, indicating an increasing negative influence of internet penetration in emissions reduction, with income growth and the environmental effects of the internet evolving from direct and indirect to systemic.

\section{Discussion and Conclusions}

The internet has profoundly revolutionized the pattern of economic growth and led to countervailing environmental effects. This study empirically investigates the validity of inverted $\mathrm{U}$-shaped income-emission paths and the ways in which internet penetration influences the EKC (i.e., the turning point) in a cross-national context.

Using data on $\mathrm{CO}_{2}$ emissions from 115 countries with multiple levels of per capita GDP and internet penetration from 1996 to 2014, this analysis presents results supporting the validity of the EKC hypothesis and reveals that internet penetration could generally reduce the actual income level beyond which pollution begins to decrease. Further tests, based on the division of income and period, indicate an increasing negative influence of internet penetration on emission reduction, with income growth 
and the environmental effects of the internet evolving from direct and indirect to systemic. We also demonstrate that the level of urbanization, industrialization, and population pressure have negative effects on environmental quality, while higher proportions of the elderly and female populations in a country indicate lower carbon emissions.

This is the first analysis that demonstrates the direct effects of internet penetration on the EKC and its economic threshold. The empirical finding that internet penetration adversely impacts the ecological system in developed and less developed countries contributes to the literature by paving the way for a new mechanism with which to interpret the controversy surrounding the validity of the EKC, as well as exploring the environmental impacts of the internet in different economic conditions and development stages.

This study has important implications for further research. First, though the EKC has been widely used to explain the income-environment path [4], it is apparently not the same for all countries and is influenced by various factors [1,2,4]. Further EKC studies should pay more attention to the differences between developed and less developed countries, and among countries with different endogenous and exogenous conditions, as Dinda (2004) and Lv (2017) have noted [2,52]. Second, an analysis of the implications of internet penetration on environment should be conducted within specific economic and social conditions. Given that the internet has not yet been involved in the dominant factors that interpret the EKC hypothesis, dynamic and integrated investigative frameworks should be built to capture the countervailing environmental impact of the internet. Compared with the separated analysis concentrating on the direct environmental impacts of the internet at an economic level, as Williams (2011) points out, further systemic recognition of how the internet interacts with environmental issues would be beneficial for interpretations of the income-environment path and for formulating policies [13].

Turning to policy implications, the documented economic thresholds of the EKC are usually too high for most countries in the world to reach $[3,53]$. The overall negative impact of internet penetration on the economic threshold of the EKC, as demonstrated in our empirical results, gives an optimistic insight into the evolution of global environmental quality. As such, environmental degradation should not be treated just as an economic issue in this respect; therefore, economic growth is not the panacea to all existing and latent environmental issues [7]. Information and internet technologies, if properly introduced and used, could play a vital role in emissions reduction and further improvements in environmental quality, in addition to enhancing economic growth [29]. Latecomer countries do not need to follow the growth-pollution path exhibited by developed countries, and should make environmental improvements at a low-income threshold [28]. For this purpose, it is necessary for the authorities to take into account the environmental effects of the internet technologies they introduce and use. Meanwhile, governments should exploit and apply the capabilities of the internet in regard to achieving sustainable development and green growth, including higher accuracy in environmental monitoring and evaluation, cleaner processes in production and supply chains, and greater efficiency in energy consumption and energy substitution.

Nevertheless, the heterogeneity of the environmental effects of the internet across countries in different income and period divisions indicates that a type of "environmental catching up", brought about by internet use, will not necessarily occur in a global context [9]. As for low-income countries, the direct economic impact of internet use will lead to more environmental deterioration, as internet penetration has not led to sustainable evolution at a societal level; that is, the stimulated systematic socialization of environmental technologies has not yet been achieved. Besides the internet-based sustainable economic pattern, systemic effects place greater emphasis on internet-enhanced environmental governance mechanisms, which are more significant to the government, environmental groups, and the general public. In terms of policy formulations in less developed countries, the government should take advantage of the internet in regard to cultivating ecological awareness and transforming environmental governance, aiming to reach a 
consensus about the environment across parties and formulate adaptive collaborative partnerships in environmental governance.

It should be noted that this analysis is limited to the time period and countries investigated. Given that the internet is diffusing and penetrating quite rapidly, further follow-up studies on the environmental impacts of internet penetration should be conducted once the WDI has published newly data on $\mathrm{CO}_{2}$ emissions or has provided other reliable data sources. Moreover, we suggest that further research should be conducted in a regional or individual national context, in order to reveal the systemic effects of the internet on environment from the perspectives of economic and societal visions.

Author Contributions: This research was designed and carried out by Z.Z. and X.M. The paper was written by Z.Z. and was revised and checked by X.M. Both authors read and approved the final manuscript.

Funding: This article was funded by the National Natural Science Foundation of China under Grant 71573185, by the Ministry of Education of the People's Republic of China under Grant 14YJC630100, and by the National Social Science Foundation of China under Grant 18FZZ003.

Acknowledgments: The authors greatly appreciate the advice and professional comments received from the anonymous reviewers and the editor.

Conflicts of Interest: The authors declare no conflicts of interest.

\section{References}

1. Grossman, G.M.; Krueger, A.B. Environmental Impacts of a North American Free Trade Agreement. NBER Working Papers Series. 1991. Available online: https://www.nber.org/papers/w3914 (accessed on 11 February 2019).

2. Dinda, S. Environmental Kuznets curve hypothesis: A survey. Ecol. Econ. 2004, 49, 431-455. [CrossRef]

3. Mazur, A.; Phutkaradze, Z.; Phutkaradze, J. Economic growth and environmental quality in the European Union countries: Is there evidence for the environmental Kuznets curve? Int. J. Manag. Econ. 2015, 45, 108-126. [CrossRef]

4. Kijima, M.; Nishide, K.; Ohyama, A. Economic models for the environmental Kuznets curve: A survey. J. Econ. Dyn. Control 2010, 34, 1187-1201. [CrossRef]

5. Arouri, M.H.; Youssef, A.B.; M'Henni, H.; Rault, C. Energy consumption, economic growth and $\mathrm{CO}_{2}$ emissions in Middle East and North African countries. Energy Policy. 2012, 45, 342-349. [CrossRef]

6. Apergis, N.; Ozturk, I. Testing Environmental Kuznets Curve hypothesis in Asian countries. Ecol. Indic. 2015, 52, 16-22. [CrossRef]

7. Gill, A.R.; Viswanathan, K.K.; Hassan, S. A test of environmental Kuznets curve (EKC) for carbon emission and potential of renewable energy to reduce green-house gases (GHG) in Malaysia. Environ. Dev. Sustain. 2018, 20, 1103-1114. [CrossRef]

8. Al-Mulali, U.; Saboori, B.; Ozturk, I. Investigating the environmental Kuznets curve hypothesis in Vietnam. Energy Policy 2015, 76, 123-131. [CrossRef]

9. Baiardi, D. Technological progress and the environmental Kuznets curve in the twenty regions of Italy. BE J. Econ. Anal. Policy 2014, 14, 1501-1542. [CrossRef]

10. Chen, A.J.W.; Boudreau, M.; Watson, R.T. Information systems and ecological sustainability. J. Syst. Inf. Technol. 2008, 10, 186-201. [CrossRef]

11. Wang, Y.; Hao, F. Does internet penetration encourage sustainable consumption? A cross- national analysis. Sustain. Prod. Consum. 2018, 16, 237-248. [CrossRef]

12. Gonel, F.; Akinci, A. How does ICT-use improve the environment? The case of Turkey. World J. Sci. Technol. Sustain. Dev. 2018, 15, 2-12. [CrossRef]

13. Williams, E.D. Environmental effects of information and communications technologies. Nature 2011, 479, 354. [CrossRef] [PubMed]

14. Belkhir, L.; Elmeligi, A. Assessing ICT global emissions footprint: Trends to 2040 \& recommendations. J. Clean. Prod. 2018, 177, 448-463.

15. Yi, L.; Thomas, H.R. A review of research on the environmental impact of e-business and ICT. Environ. Int. 2007, 33, 841-849. [CrossRef] [PubMed] 
16. Shrouf, F.; Ordieres, J.; Miragliotta, G. Smart factories in Industry 4.0: A review of the concept and of energy management approached in production based on the Internet of Things paradigm. In Proceedings of the 2014 IEEE International Conference on Industrial Engineering and Engineering Management, Selangor, Malaysia, 9-12 December 2014; pp. 697-701.

17. Ellegård, K.; Palm, J. Visualizing energy consumption activities as a tool for making everyday life more sustainable. Appl. Energy. 2011, 88, 1920-1926. [CrossRef]

18. Purdy, S.J. Internet use and civic engagement: A structural equation approach. Comput. Hum. Behav. 2017, 71, 318-326. [CrossRef]

19. West, D.M. E-government and the transformation of service delivery and citizen attitudes. Public Adm. Rev. 2004, 64, 15-27. [CrossRef]

20. He, G.; Boas, I.; Mol, A.P.J.; Lu, Y. E-participation for environmental sustainability in transitional urban China. Sustain. Sci. 2017, 12, 187-202. [CrossRef]

21. Bond, R.M.; Fariss, C.J.; Jones, J.J.; Kramer, A.D.; Marlow, C.; Settle, J.E.; Fowler, J.H. A 61- million-person experiment in social influence and political mobilization. Nature 2012, 489, 295-298. [CrossRef] [PubMed]

22. Deng, L.; Babbitt, C.W.; Williams, E.D. Economic-balance hybrid LCA extended with uncertainty analysis: Case study of a laptop computer. J. Clean. Prod. 2011, 19, 1198-1206. [CrossRef]

23. Hertwich, E.G.; Roux, C. Greenhouse gas emissions from the consumption of electric and electronic equipment by Norwegian households. Environ. Sci. Technol. 2011, 45, 8190-8196. [CrossRef] [PubMed]

24. Malmodin, J.; Moberg, Å.; Lundén, D.; Finnveden, G.; Lövehagen, N. Greenhouse gas emissions and operational electricity use in the ICT and entertainment \& media sectors. J. Ind. Ecol. 2010, 14, 770-790.

25. Webb, M. Smart 2020: Enabling the Low Carbon Economy in the Information Age. Available online: https: / / www.theclimategroup.org/sites/default/files/archive/files/Smart2020Report.pdf (accessed on 11 February 2019).

26. Robinson, B.H. E-waste: An assessment of global production and environmental impacts. Sci. Total Environ. 2009, 408, 183-191. [CrossRef] [PubMed]

27. Berkhout, F.; Hertin, J. Impacts of information and communication technologies on environmental sustainability: Speculations and evidence. OECD Report Sussex: SPRU-Science and Technology Policy Research. 2001. Available online: http://www.oecd.org/science/inno/1897156.pdf (accessed on 11 February 2019).

28. Panayotou, T. Demystifying the environmental Kuznets curve: Turning a black box into a policy tool. Environ. Dev. Econ. 1997, 2, 465-484. [CrossRef]

29. Choi, C.; Yi, M.H. The effect of the internet on economic growth: Evidence from cross-country panel data. Econ. Lett. 2009, 105, 39-41. [CrossRef]

30. Zaim, O.; Taskin, F. A Kuznets curve in environmental efficiency: An application on OECD countries. Environ. Resour. Econ. 2000, 17, 21-36. [CrossRef]

31. Copeland, B.R.; Taylor, M.S. Trade, growth and the environment. J. Econ. Lit. 2004, 42, 7-71. [CrossRef]

32. Bradford, D.F.; Fender, R.A.; Shore, S.H.; Wagner, M. The environmental Kuznets curve: Exploring a fresh specification. Contr. Econ. Anal. Policy. 2005, 4, 1-28. [CrossRef]

33. Wagner, M. The carbon Kuznets curve: A cloudy picture emitted by bad econometrics? Resour. Energy Econ. 2008, 30, 388-408. [CrossRef]

34. Leitão, A. Corruption and the environmental Kuznets curve: Empirical evidence for sulfur. Ecol. Econ. 2010, 69, 2191-2201. [CrossRef]

35. Mossberger, K.; Tolbert, C.J.; Hamilton, A. Measuring digital citizenship: Mobile access and broadband. Int. J. Commun. 2012, 6, 2492-2528.

36. Ding, Y.; Peng, J. Impacts of urbanization of mountainous areas on resources and environment: Based on ecological footprint model. Sustainability 2018, 10, 765. [CrossRef]

37. Menz, T.; Welsch, H. Population aging and environmental preferences in OECD countries: The case of air pollution. Ecol. Econ. 2010, 69, 2582-2589. [CrossRef]

38. York, R. Demographic trends and energy consumption in European Union Nations, 1960-2025. Soc. Sci. Res. 2007, 36, 855-872. [CrossRef]

39. Zelezny, L.C.; Chua, P.; Aldrich, C. Elaborating on gender differences in environmentalism. J. Soc. Issues. 2000, 56, 443-457. [CrossRef] 
40. Dietz, T.; Rosa, E.A. Effects of population and affluence on $\mathrm{CO}_{2}$ emissions. Proc. Natl. Acad. Sci. USA 1997, 94, 175-179. [CrossRef]

41. Payne, R.A. Freedom and the environment. J. Democr. 1995, 6, 41-55. [CrossRef]

42. You, W.H.; Zhu, H.M.; Yu, K.M.; Peng, C. Democracy, financial openness, and global carbon dioxide emissions: Heterogeneity across existing emission levels. World Dev. 2015, 66, 189-207. [CrossRef]

43. Midlarsky, M.I. Democracy and the environment: An empirical assessment. J. Peac. Res. 1998, 35, 341-361. [CrossRef]

44. Ferguson, R.; Wilkinson, W.; Hill, R. Electricity use and economic development. Energy Policy. 2000, 28, 923-934. [CrossRef]

45. Frankel, J.A.; Romer, D. Does trade cause growth? Am. Econ. Rev. 1999, 89, 379-399. [CrossRef]

46. Alfaro, L.; Chanda, A.; Kalemli-Ozcan, S.; Sayek, S. FDI and economic growth: The role of local financial markets. J. Int. Econ. 2002, 64, 89-112. [CrossRef]

47. Li, H.; Li, Y.; Lee, M.; Liu, Z.; Miao, C. Spatiotemporal analysis of heavy metal water pollution in transitional China. Sustainability 2015, 7, 9067-9087. [CrossRef]

48. Karki, S.K.; Mann, M.D.; Salehfar, H. Energy and environment in the ASEAN: Challenges and opportunities. Energy Policy 2005, 33, 499-509. [CrossRef]

49. Lad, R.K.; Desai, N.G.; Christian, R.A.; Deshpande, W. Fuzzy modeling for environmental pollution potential ranking of industries. Environ. Prog. 2008, 27, 84-90. [CrossRef]

50. Heilbronner, R.L. An Inquiry into the Human Prospect; W.W. Norton \& Company: New York, NY, USA, 1974.

51. Congleton, R.D. Political institutions and pollution control. Rev. Econ. Stat. 1992, 74, 412-421. [CrossRef]

52. $\mathrm{Lv}, \mathrm{Z}$. The effect of democracy on $\mathrm{CO}_{2}$ emissions in emerging countries: Does the level of income matter? Renew. Sustain. Energy Rev. 2017, 72, 900-906. [CrossRef]

53. List, J.A.; Gallet, C.A. The Environmental Kuznets Curve: Does one size fit all? Ecol. Econ. 1999, 31, 409-423. [CrossRef]

(C) 2019 by the authors. Licensee MDPI, Basel, Switzerland. This article is an open access article distributed under the terms and conditions of the Creative Commons Attribution (CC BY) license (http:/ / creativecommons.org/licenses/by/4.0/). 